\title{
Appropriate placement of vapour recompression in ultra-low energy industrial milk evaporation systems using Pinch Analysis
}

\author{
Timothy G. Walmsley*, Martin J. Atkins, Michael R.W. Walmsley, James R. Neale \\ University of Waikato, Energy Research Centre, School of Engineering, Hamilton, New Zealand
}

\section{A R T I C L E I N F O}

\section{Article history:}

Received 31 December 2015

Received in revised form

6 March 2016

Accepted 6 April 2016

Available online $\mathrm{xxx}$

\section{Keywords:}

Pinch Analysis

Evaporation systems

Process Integration

Dairy processing

Vapour recompression

\begin{abstract}
A B S T R A C T
This study focuses on applying Pinch Analysis to an industrial milk evaporator case study to quantify the potential energy savings. Modern milk evaporators are typically integrated using both mechanical and thermal vapour recompression technologies as the primary means for attaining a high level of energy efficiency. A significant step change in energy efficiency for milk evaporators is achieved in this study by appropriate placement of vapour recompression in a new improved two-effect milk evaporation system design. The Grand Composite Curve helps identify areas for process modifications and placements of vapour recompression that result in energy reduction. In particular, the innovative placement of Mechanical Vapour Recompression in the system unlocks significant energy, energy cost, and emissions savings. The new design requires $78 \%$ less steam (6397 kW) at the expense of $16 \%$ (364 $\mathrm{kW}_{\text {ele }}$ ) more electricity use. The estimated cost savings associated with the improved design is $\$ 942,601 / \mathrm{y}$ and the emissions reduction is $3416 \mathrm{t} \mathrm{CO}_{2}-\mathrm{e} / \mathrm{y}$. Further energy efficiency improvements and cost savings of $\$ 1,411,844 / y$ are gained through improved Total Site Heat Integration through recovery of waste heat from the dryer exhaust air and boiler return condensate streams.
\end{abstract}

๑) 2016 Elsevier Ltd. All rights reserved.

\section{Introduction}

Increasing sustainability in food processing through increased processing energy efficiency is a topic of significant global interest [1]. Rising pressure to lower energy use and emissions in all sectors of society are driving the need for energy efficiency related research and implementation [2]. In New Zealand, the food processing sector is dominated by dairy processing with milk powders being the principal product for export. Conversion of liquid milk to powdered milk is an energy intensive two-stage process that uses between 5.2 and $11.1 \mathrm{GJ} / \mathrm{t}$ of product depending on the plant's vintage [3]. The first dewatering stage, which is the focal point of the present study, is a multi-effect evaporator train. The second dewatering stage is spray drying, which typically has minimal heat integration [4].

A series of recent studies into the reduction of energy use of milk powder production using Process Integration techniques have chiefly given attention to spray dryer exhaust heat recovery as the key to advancing to the next level of energy efficiency. Focuses of these studies have included optimisation of soft temperatures for

\footnotetext{
* Corresponding author.

E-mail address: timgw@waikato.ac.nz (T.G. Walmsley).
}

minimising energy use [5], development of HEN (Heat Exchanger Networks) [6], dryer heat recovery modelling [7], and development of a comprehensive economic optimisation of the dryer exhaust heat recovery system [8]. Although the evaporation system was included in some of these studies, the finer details and constraints surrounding the entire evaporation system, including the milk heat treatment section, were not fully appreciated. As a result, improvements in the thermal and electrical energy efficiency for the milk evaporator plant were limited.

Published studies on milk evaporation systems have chiefly focused on the stand-alone energy efficiency of the individual process; without considering a holistic Process Integration approach to designing an evaporation system that optimally integrates with the entire milk powder process [9]. For example, Hanneman and Robertson [10] compared a five-effect milk evaporator train integrated with TVR (thermal vapour recompression) to a single evaporator effect integrated with MVR (mechanical vapour recompression). Their analysis reported the MVR scheme required 55\% less fuel use, however their analysis failed to account for any required vapour bleeds and condensers that may be integrated as a heat source in the surrounding process. Available industrial documentation from GEA Niro, a global industrial milk evaporator supplier, presents set-ups and operation techniques for 


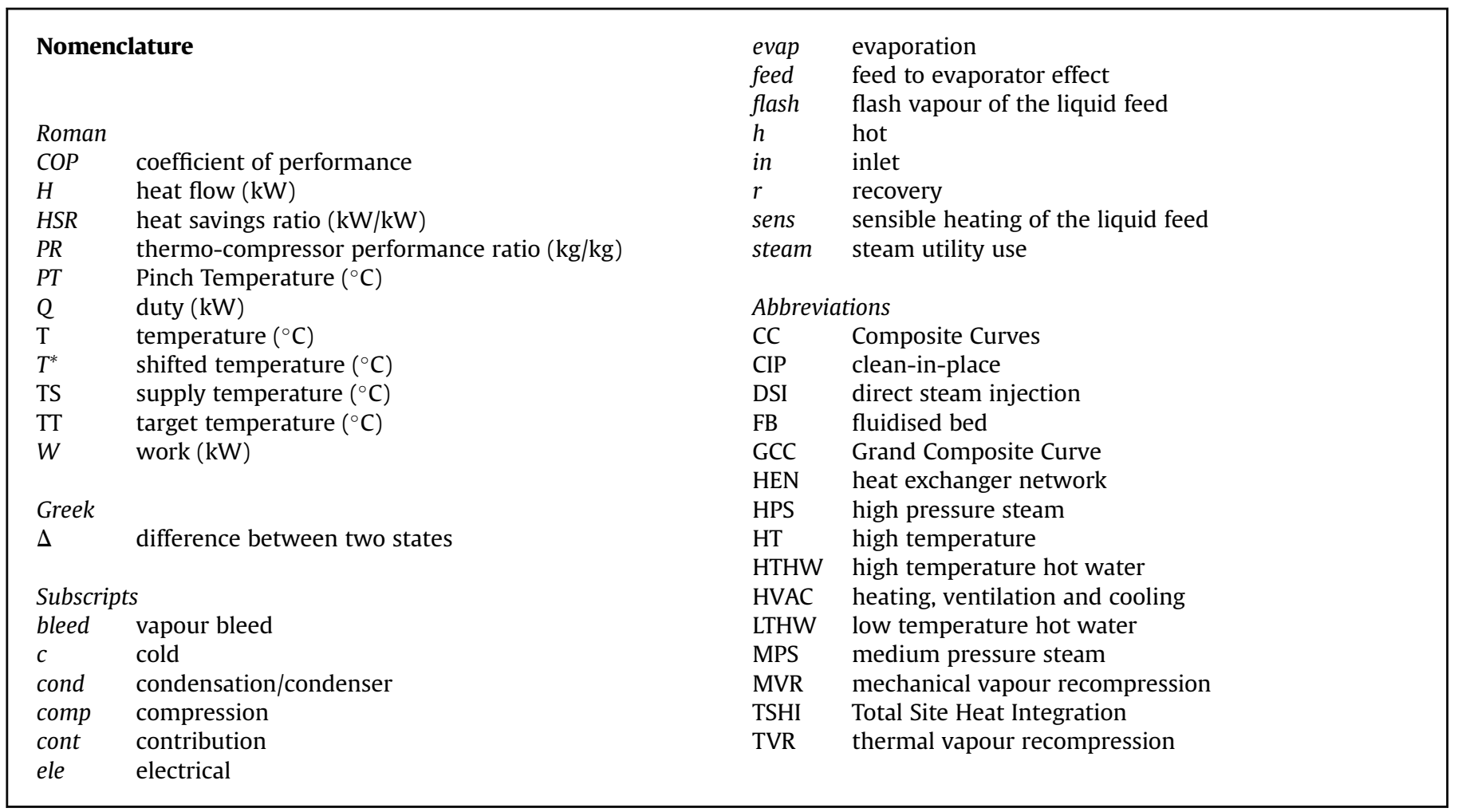

milk evaporators, which achieve a high-energy economy [11], but these are often sub-optimal with respect to an entire site. It is anticipated that applications of Process Integration techniques to the milk evaporation system problem will yield substantial economic steam savings, as have been found for other industries [12].

Thermal and mechanical vapour recompression technologies find excellent application in a wide range of processing systems. TVR uses a thermocompressor with high pressure vapour (steam utility) to recompress low pressure vapour (often under vacuum) to a slightly higher pressure and temperature. MVR uses a mechanical fan, normally driven by electricity, to recompress low pressure vapour to a slightly higher pressure and temperature. In distillation systems, MRV can directly compress top distillate vapour for use in the reboiler or can indirectly recovery heat from the distillate vapour using a separate working fluid such as n-pentane before upgrade and use in the reboiler. These processing structures led to a step-change in energy integration [13]. In desalination systems, multi-effect evaporation systems integrated with an absorption heat pump and vapour compression cycles can effectively synthesize to generate cooling and fresh clean water at $26 \%$ lower total cost compared to [14]. TVR has found application in carbon capture processes to upgrade and recovery of waste, resulting in energy savings between 10 and $14 \%$ [15]. In milk evaporation systems, vapour recompression units directly compress vapour flows drawn from the product on the tube-side ("evaporator") to a higher pressure and temperature for use as the condensing vapour on the shell-side ("condenser"). As a result, this arrangement creates a so called open cycle heat pump. The analogy between vapour recompression and conventional heat pumps also extends to the idea of appropriate placement in Pinch Analysis, which states that a heat pump should upgrade heat from below the Pinch for use above the Pinch [16].

Purposeful design and integration of the evaporation system to complement the heat demands of neighbouring processes provides greater opportunities for energy and emissions savings. TSHI (Total
Site Heat Integration) provides a valuable framework for understanding and optimising the site-wide heat balance [17,18]. Application of TSHI has recently led to substantial utility savings in slaughter and meat processing [19], large industrial parks in Japan [20] and Thailand [21], chemical processing clusters [16,17], and Kraft pulp mills [23]. With respect to the milk evaporation system design problem, TSHI can help determine the value of heat exports from the evaporation system to neighbouring processes.

The aim of this study is to develop an ultra-low energy design for a milk evaporation system through the appropriate placement of vapour recompression, given the context of a stand-alone milk powder factory. To achieve this aim, a combination of Pinch Analysis, TSHI, and process modelling techniques are applied to the milk evaporation system problem to identify critical components of an ultra-low energy evaporation system design. A modern industrial two-effect evaporator case study provides a useful starting point, comparison, and scope for the new evaporation system design. To ensure a fair comparison, the new design is constrained to have the same number of effects as the industrial base case. Milk processing constraints related to product quality, thermal treatment, and thermophile growth, are important considerations in the solution development. In particular, the GCC (Grand Composite Curve) plays an important role in the analysis to help identify where process modifications and vapour recompression can be considered to provide a step change in energy efficiency. Targets for energy use, energy cost, and emissions are calculated to determine the benefits of shifting towards an ultra-low energy milk evaporation system. The presented analysis is an extension of the early work by the authors [9].

\section{Historical developments in energy efficiency of industrial milk evaporation systems in New Zealand}

Over the past four decades, there has been significant progress in the design and efficiency of milk evaporators in the New Zealand 
dairy industry. The presented historical developments are based on generalised historical design trends for New Zealand milk powder factories, but there are individual exceptions.

Plants built in the 1980s tended to have installed either a conventional four or seven-effect milk evaporator system. Four-effect milk evaporators have a COP (Co-efficient of Performance), i.e. the ratio of evaporation in $\mathrm{kJ}$ to energy input in $\mathrm{kJ}$, of about 4 and the systems reject $560 \mathrm{MJ} / \mathrm{t}_{\text {evap }}$ of low-grade heat through cooling towers and in discharged warm condensate streams due to low overall heat integration.

In the early 1990's, the new vintage of plants favoured foureffect evaporation systems with integrated TVR. These evaporation systems achieve a COP of about 7. Heat integration between the evaporators and the background processes was also improved compared to earlier designs and, consequently, about $300 \mathrm{MJ} / \mathrm{t}_{\text {evap }}$ of heat is rejected in cooling towers and discharged condensate flows.

Milk evaporator designs since mid-1990 have mostly used a combination of MVR and TVR technologies in either two or three effect arrangements. The overall COP of these evaporation systems are about 30 and may no longer need a cooling tower to reject lowgrade heat. However, unrecovered low-grade heat of about $83 \mathrm{MJ} /$ $t_{\text {evap }}$ is contained in discharged condensate streams $\left(25-35^{\circ} \mathrm{C}\right)$ that are seemingly above the milk powder plant's hot Pinch Temperature $\left(13^{\circ} \mathrm{C}\right)[5]$.

Improvements in energy efficiency of milk evaporation systems in New Zealand, however, have been marginal since the shift to MVR/TVR combinations. Industry practice with respect to energy efficiency of the evaporation system has plateaued. The questions addressed by this work are: Does the current energy efficiency plateau represents a thermodynamic limit for these systems? Are further step-changes in energy efficiency possible? And, what are the key design elements that will enable such a step change in energy efficiency?

\section{An elementary analysis of integrated evaporation systems}

The design and set-up of an evaporation system plays a fundamental role in determining the thermodynamic energy efficiency potentials of a system. As a result, it is first important to understand the simple Pinch Analysis concept of an ideal integrated evaporation system [12], which can help maximise the degree of energy recovery for an entire system. Simple illustrations in Fig. 1 are used to describe this concept for multi-effect evaporation systems with and without vapour recompression. The effect of vapour recompression on the overall heat balance is also critical to the present work. As a result, heat balances of single effect evaporation systems with MVR and TVR and various liquid feed temperatures, $T_{\text {feed }}$, relative to the evaporation temperature, which affect the availability of heat for recovery from an evaporation system, are illustrated in Fig. 2. To help demonstrate various principles in this section, the heat load profiles of the evaporation system, i.e. the evaporation and condensation heat loads in each effect, are presented separate to the background process heat load.

The ideal integration of evaporation systems depends on the required evaporation load compared to the heating and cooling needs of the background processes, which can be represented as a GCC (Fig. 1). Multi-effect evaporation systems are preferably integrated so that the system fits either above the Pinch as a source (Fig. 1a), below the Pinch as a sink (Fig. 1b), or inside a heat recovery pocket of the background GCC (not shown), in such a way that no extra utility is needed beyond the demands of the background processes [24]. It is also possible to position evaporator effects either side of the Pinch Temperature without increasing overall utility consumption, but not across the Pinch Temperature.
If the hypothetical net heat load cascade of the background processes is reduced relative to the evaporation system load as illustrated in Fig. 1c and d, one may choose to increase the number of evaporator effects to offset the lower inter-system heat integration potential. However, there are many situations where increasing the number of effects is not technically feasible and/or economically viable. For such situations, integration of vapour recompression in evaporation systems provides an alternate method for reducing utility demand while potentially using less evaporator effects.

TVR appropriately integrates into evaporation systems that are above the Pinch Temperature of the background processes, as illustrated in Fig. 1c. TVR uses high-pressure steam utility to provide the work to recompress some of the low-pressure evaporated vapour using a thermocompressor (Fig. 2a, c, and e). The remaining low-pressure vapour exiting the tube-side condenses in a condenser. The condenser duty depends on the performance ratio of the thermocompressor, which is characteristic to a particular design [25], and the liquid feed temperature. Thermocompressor performance ratio, $P R$, is

$$
P R \equiv \frac{\dot{m}_{u p g}}{\dot{m}_{u t, s t}}
$$

Heat from the condenser and subsequent warm condensate streams ideally cascade as a heat sources for the background processes. If not, utility use will increase by $\Delta Q_{h}$ and $\Delta Q_{c}$, as illustrated for the TVR system in Fig. 1c. As a result, if the condenser heat is composited into the background process GCC, the inclusion will change the Pinch Temperature to be driven by the evaporation system, such as the condenser pressure. For such situations, MVR may consider as an alternate vapour recompression method because that inputs less energy (electricity) and therefore outputs less waste heat, preventing the increase in steam consumption.

MVR also appropriately integrates into evaporation systems that are above the Pinch Temperature of the background process (Fig. 1d), although it may also be used below Pinch if multi-effect evaporation is not possible. It is important to note that if the evaporation and condensation loads of the evaporator were added to the background, the Pinch Temperature of the combined process would be driven by the evaporation system. Implementation of MVR therefore follows the appropriate placement principle for heat pumps, i.e. heat is upgraded from below the Pinch to above the Pinch.

MVR integrated effects commonly recompress all the lowpressure evaporated vapour on the tube-side to the shell-side pressure (Fig. 2 b, d, and f). A vapour bleed from the shell-side of the effect is normally requisite to balance the evaporation and condensation loads. The vapour bleed is an additional heat source for the background processes. If liquid feed is overly subcooled, i.e. $T_{\text {feed }}<T_{\text {evap }}$, steam utility (or recovered heat) may be consumed to pre-heat the liquid feed before entering the evaporator (or to inject it into the shell-side of the evaporator) in order to reach the desired evaporation load and therefore production rate (Fig. 2e). The required work of compression, $W_{\text {comp }}$, is primarily dependent on the initial vapour pressure and its required temperature lift. Unlike TVR systems, MVR integrated systems does not benefit from multieffect arrangements. A limitation of MVR units is the maximum saturation temperature lift achieved by a single MVR unit is nominally $8{ }^{\circ} \mathrm{C}$. When larger pressure and temperature lifts are needed, MVR fans can be placed in series. Combinations of MVR and TVR as part of an evaporation system above the Pinch may also be designed to match the GCC of the background processes, which minimises utility consumption and operating energy cost. 


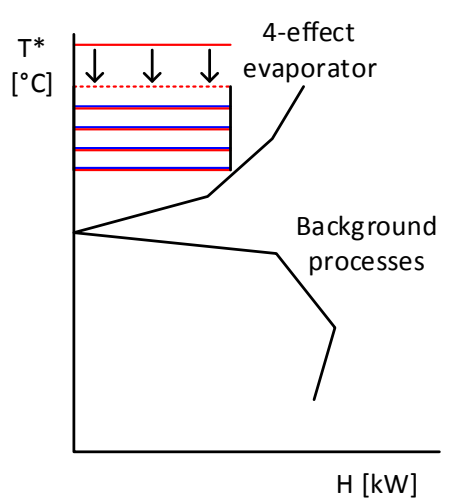

(a) 4-effects above pinch

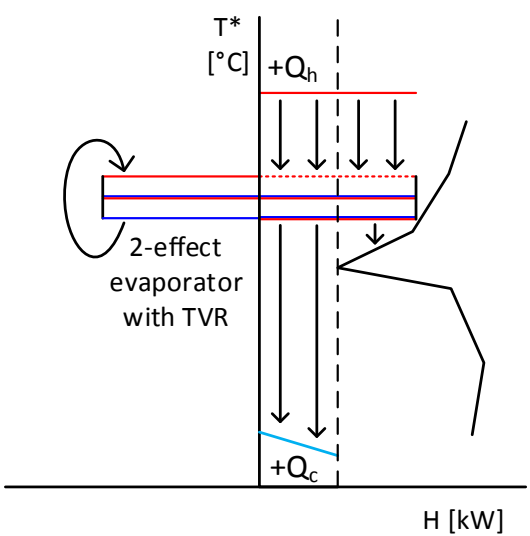

(c) 2-effects above pinch with TVR

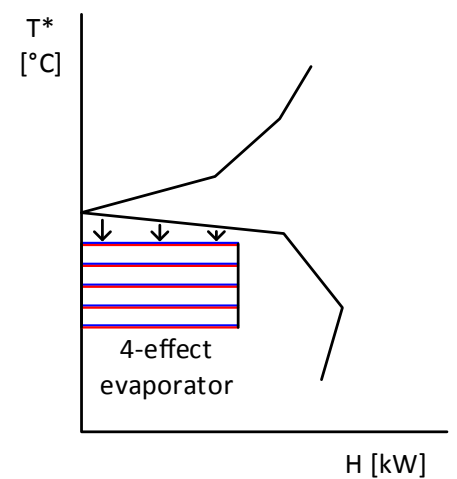

(b) 4-effects below pinch

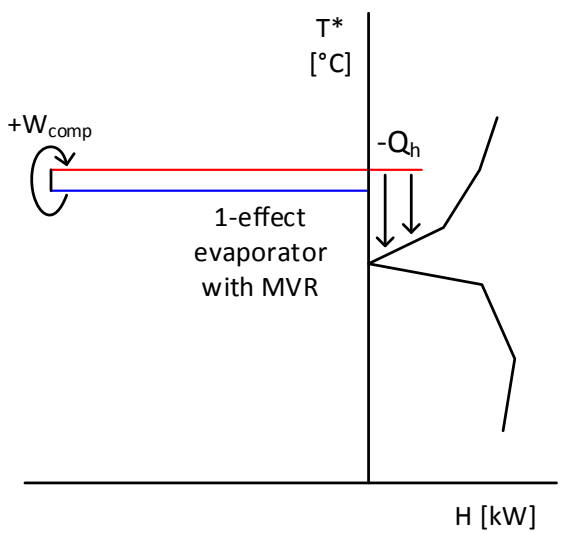

(d) 1-effects above pinch with MVR

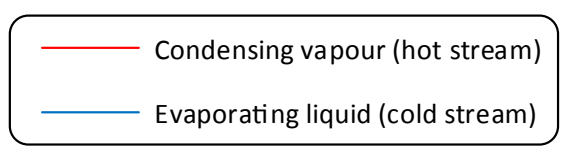

Fig. 1. Conceptual integration of evaporation systems including vapour recompression with background processes.

\section{Methodology}

A sequential design and optimisation approach following the process design analogy of the Onion Diagram [26] has been taken in this investigation. At the core of the Onion Diagram is the reactor system, followed (in order) by layers for the separation system, the HEN, the utility system, and waste treatment. In the case of a milk evaporation system, there is no so called reactor; rather, the evaporator design, which includes the arrangement and number of effects, may be considered as the core of the system (i.e. the separation system), which is surrounded by a HEN. Starting with a modern evaporation system design as the base case, the study presents analysis of the following scenarios:

1. Improvements for the HEN given the base case evaporator design;

2. Process temperature modification for improved heat recovery given the base case evaporator design;

3. Appropriate selection and placement of vapour recompression for a new evaporator system design;

4. Design of the HEN; and,

5. Heat import and export targets for TSHI for the base case design and new designs.
To target these scenarios, a combination of process modelling, Pinch Analysis, and TSHI form the basis of the targeting, design, and optimisation analysis for milk evaporators. Process modelling helps determine the multiple downstream effects from making a process modification. Pinch Analysis is applied to calculate heat recovery and utility targets for a given set of stream data. The Pinch Design Method is applied to design the HEN. TSHI helps determine the value of heat exports from the evaporation system given a correctly integrated site.

\subsection{Process model description}

A detailed heat and mass balance process model of a multieffect falling film milk evaporator system, including both MVR and/or TVR, has been implemented in an Excel ${ }^{\mathrm{TM}}$ spreadsheet. The model has been validated for the current set-up using the industrial plant data. The model applies standard water/steam properties (IAPWS IF-97) and milk properties [27]. Based on industrial data, low pressure mechanical compressors (MVR) have a calculated isentropic efficiency of $80 \%$. Thermocompressor performance is modelled using the model of Sargolzaei et al. [28], assuming choked flow through the thermocompressor. The model was applied to test various retrofit and new build concepts to determine the impact on overall energy efficiency. As the proposed concepts are applied, the 


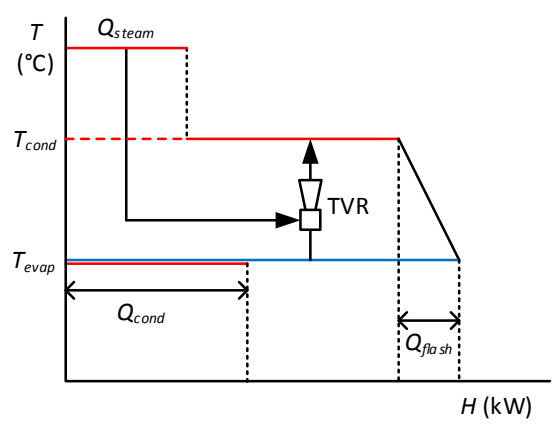

(a) TVR, $T_{\text {feed }}>T_{\text {evap }}$

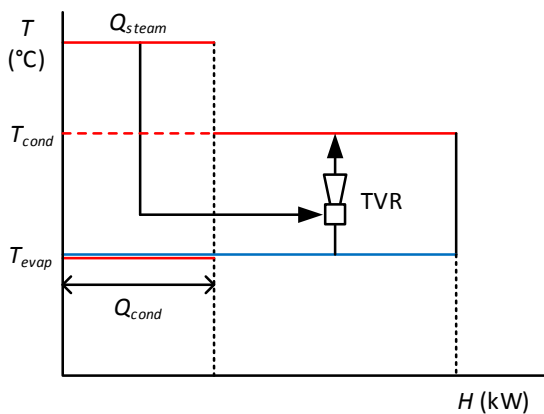

(c) TVR, $T_{\text {feed }}=T_{\text {evap }}$

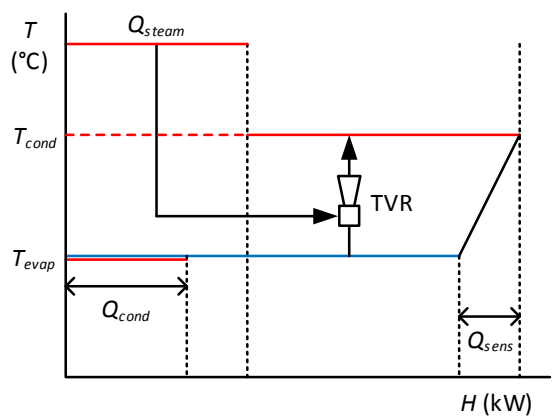

(e) TVR, $T_{\text {feed }}<T_{\text {evap }}$

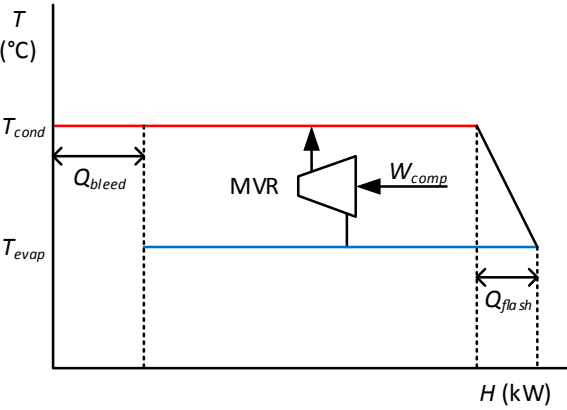

(b) MVR, $T_{\text {feed }}>T_{\text {evap }}$

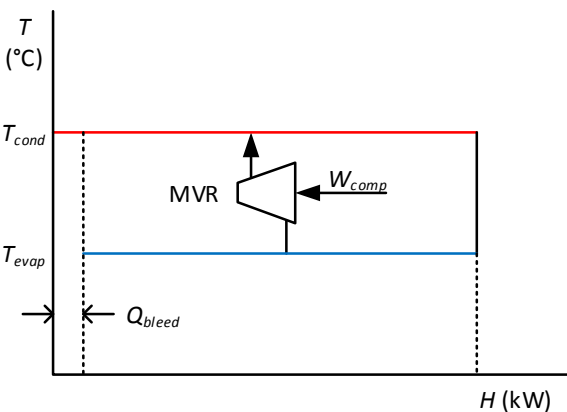

(d) MVR, $T_{\text {feed }}=T_{\text {evap }}$

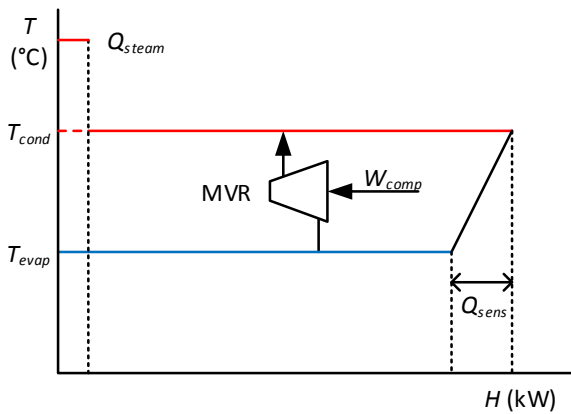

(f) MVR, $T_{\text {feed }}<T_{\text {evap }}$

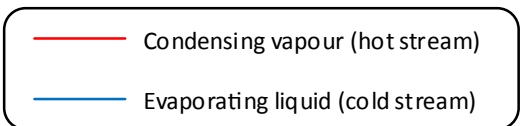

Fig. 2. Heat balances of single evaporator effects integrated with MVR and TVR with the same evaporation duty.

mass and energy balance model recalculates, which in turn affects the PA stream data and the calculated Pinch targets.

\subsection{Process and Total Site Heat Integration targeting}

Pinch Analysis techniques for evaporation systems [12] have been applied to calculate utility and heat recovery targets for the evaporation processing zone. The inclusion of vapour recompression into the evaporation system is based on the appropriate placement principle for heat pumps [16]. A Heat Savings Ratio is calculated to determine the effectiveness of integrating vapour recompression into the evaporation system. The HSR is defined as

$H S R \equiv \frac{Q_{h, \text { reduction }}}{Q_{\text {in }}}, \quad$ where $Q_{\text {in }}=\left\{\begin{array}{l}W_{\text {comp }} \in \mathrm{MVR} \\ Q_{\text {steam }} \in \mathrm{TVR}\end{array}\right.$

TSHI (Total Site Heat Integration) [18] has been applied to understand the integration potential between the evaporation system and the remainder of the milk powder processes. Utility use has been targeted at the process level and later combined and matched for TSHI. Targeting utilities at the process level ensures targets for hot water systems are realistic.

\section{Industrial milk evaporation system case study}

\subsection{Process description and processing constraints}

Milk evaporators have several upstream and downstream processes that provide opportunities for heat integration. These milk processing steps also have a number of processing constraints that must be satisfied to obtain an industrially acceptable solution.

Important upstream processes of the evaporation system include a milk separation process, which includes cream pasteurisation, and a milk heat treatment process. At modern factories, the milk separation process separates raw milk from the farm into skim 
milk and cream, while the fluids are cold $\left(\sim 8^{\circ} \mathrm{C}\right)$. Older designs use a hot separation process $\left(\sim 45^{\circ} \mathrm{C}\right)$ with greater energy demand. The new cold milk separation technology requires about $10 \mathrm{MJ} / \mathrm{t}_{\mathrm{p}}$ of hot water utility and $10 \mathrm{MJ} / \mathrm{t}_{\mathrm{p}}$ of chilled water utility, which is primarily associated with cream pasteurisation. The older hot separation technology demands about $170 \mathrm{MJ} / \mathrm{t}_{\mathrm{p}}$ of hot water utility and $170 \mathrm{MJ} / \mathrm{t}_{\mathrm{p}}$ of chilled water utility. The milk separation process usually services multiple dairy processing plants, e.g. milk powder plant, cream plant, and butter plant. As a result, the scheduling of the milk separation process tends to depend on the timing of the in-flow of milk from the farm, which may differ from the production schedule of the milk powder plant. Steam availability due to differences in production schedules should be considered when analysing heat integration opportunities. In the case study, direct integration between the evaporator system and milk separation process is disallowed, rather integration through the utility system, Total Site Heat Integration, is required.

The milk heat treatment process is a combination of holding temperature $\left(80-120^{\circ} \mathrm{C}\right)$ and time $(1-60 \mathrm{~s})$, which affect the degree of protein denaturisation [29] and the flavour of the milk powder [30]. Milk enters the heat treatment process at about $8{ }^{\circ} \mathrm{C}$, i.e. its storage temperature, and heats to the heat treatment temperature, which is $94.5{ }^{\circ} \mathrm{C}$ for the case study. Conventional heat recovery via heat exchangers normally heats milk to about $80^{\circ} \mathrm{C}$. During the preheat phase, it is important to recognise that rapid thermophile growth occurs in the temperature range of $45-60{ }^{\circ} \mathrm{C}$ [31]. If conventional heat exchangers are used to preheat milk through the thermophile temperature range, two parallel processing lines, which includes duplicate heat recovery exchangers, are needed to allow for mid-evaporator run cleaning (about every $4 \mathrm{~h}$ ). If direct vapour (or steam) injection is used to heat the milk through the thermophile temperature range, the requirement of mid-run washing is avoidable, i.e. no need for parallel processing lines. Once milk exceeds $80^{\circ} \mathrm{C}$, it is important to limit contact between milk and processing equipment surfaces and to tightly control the residence time of the milk at a specific heat treatment temperature. To fulfil this constraint, DSI (direct steam injection) rapidly heats the milk to $94.5^{\circ} \mathrm{C}$, the heat treatment temperature. After being held for a short time, milk is flashed to between 80 and $85{ }^{\circ} \mathrm{C}$ for instantaneous cooling and generation of low-pressure vapour for heat recovery. In New Zealand factories, the milk heat treatment process operates on the same schedule as the evaporation system and it is directly integrated with the evaporation system.

The evaporation system follows the heat treatment process. The multi-train, multi-effect falling film evaporation system concentrates standardised milk from about $12 \%$ to $52 \%$ solids. Multiple effects improve the energy efficiency of the evaporator and the multiples train enable continuous operation. Each evaporator train is washed CIP (clean-in-place) about every $16 \mathrm{~h}$ to maintain food grade processing hygiene. The common temperature-operating window of industrial evaporator systems is $45-73{ }^{\circ} \mathrm{C}$. The upper temperature limit relates to avoiding further denaturing of proteins, which adversely affects the flavour of the final milk powder product [31].

The final processing step is the spray dryer system. After exiting the final milk evaporator effect, milk is heated to about $75{ }^{\circ} \mathrm{C}$ and homogenised before being atomised and co-currently spray dried using hot air $\left(210^{\circ} \mathrm{C}\right)$ to form milk powder. Partially dry powder from the main spray dryer chambers exits through a series of fluidised beds that provides sufficient residence time to complete the drying process and cools the powder from around $80^{\circ} \mathrm{C}$ in the main chamber to about $35^{\circ} \mathrm{C}$ in the final fluidised bed. Spent dryer air passes through cyclones and/or baghouses to help capture any entrained particles before being exhausted to the atmosphere at about $75^{\circ} \mathrm{C}$. The spray dryer and its auxiliary processing equipment is washed every $2-4$ weeks.

\subsection{Evaporation system process design and stream data}

The base-case site has a 2-effect evaporator system with integrated vapour recompression (Fig. 3). The first effect is integrated with MVR and the second effect is integrated with TVR. The MVR effect currently operates at $68^{\circ} \mathrm{C}$ (milk-side) with a duty of $115 \mathrm{MW}$ and the TVR effect operates at $56{ }^{\circ} \mathrm{C}$ (milk-side) with a duty of $5 \mathrm{MW}$. Both effects have approach temperatures of $5{ }^{\circ} \mathrm{C}$ (condensation temperature to evaporation temperature). Some vapour from the TVR effect is upgraded in a secondary thermocompressor to indirectly pre-heat milk via the shell-side of the MVR effect. Table 1 presents the measured stream data for the base case design set-up for the evaporation system, including the heat treatment process, and the spray dryer process. For Pinch Analysis, the heat treatment process is counted as part of the evaporation system zone. The Exhaust Air stream from the dryer for the purpose of the Total Site Analysis forms its own zone because it is physical distant from the other streams in the Spray Dryer Zone.

Stream flow rates are a function of the scale of production, i.e. tonnes of powder produced per hour, $\mathrm{t}_{\mathrm{p}} / \mathrm{h}$. Most stream temperatures, including the evaporator pressures/temperatures, are soft and independent of production scale. Hard temperatures include the incoming temperature of the standardised milk $\left(8^{\circ} \mathrm{C}\right)$, the milk heat treatment temperature $\left(94.5^{\circ} \mathrm{C}\right)$, the final temperature of the milk concentrate $\left(70^{\circ} \mathrm{C}\right)$, and the CIP water supply and target temperatures $\left(15^{\circ} \mathrm{C}\right.$ and $\left.85^{\circ} \mathrm{C}\right)$. Utility prices for the site in New Zealand dollars are $\$ 25.00 / \mathrm{t}$ for steam and hot water heating and $\$ 100 / \mathrm{MWh}$ for electricity. Site utility stream data is given in Table 2 . Heat integration targets are based on a $\Delta T_{\text {cont }}$ of $2.5^{\circ} \mathrm{C}$ for liquid and vapour streams and $12.5{ }^{\circ} \mathrm{C}$ for gas streams, which reflect the difference in typical heat transfer coefficients for the various fluids $\left(2-8 \mathrm{~kW} /\left[\mathrm{m}^{2 \circ} \mathrm{C}\right]\right.$ for liquid and vapour streams and $0.1 \mathrm{~kW} /\left[\mathrm{m}^{2 \circ} \mathrm{C}\right]$ for gas streams).

\section{Results and discussion for milk evaporation system case study}

\subsection{Pinch Analysis targets for base case evaporation design}

Initial applications of Pinch Analysis focus on improving the HEN of the evaporation system. CC (Composite Curves) and GCC are plotted in Fig. 4 based on the base case design. Heat transfer within the evaporator effects, which total $120,560 \mathrm{~kW}$, have been excluded from the CCs and GCCs. Heat recovery for the base case design is $18,309 \mathrm{~kW}$. The Pinch Analysis target suggests an additional heat recovery of $1322 \mathrm{~kW}$ is possible compared to the base design. The Pinch Temperature is $80.5{ }^{\circ} \mathrm{C}$. The Pinch occurs between the HT Milk Flash stream and the composite of the Cold Milk and CIP Water streams. There is also a near Pinch at $70.5{ }^{\circ} \mathrm{C}$ driven by the operating pressure of the shell-side of Effect 1 from which vapour is bled, i.e. the Vapour Bleed stream. If the minimum approach temperature is hypothetically set near $0{ }^{\circ} \mathrm{C}$, the maximum thermodynamic heat recovery is $21,037 \mathrm{~kW}$, which is $2728 \mathrm{~kW}$ (or $15 \%$ ) greater than the base case. In this extreme case, the Pinch Temperature remains driven by the soft temperature of the HT Milk Flash stream.

\subsection{Process temperature modifications for base case evaporation design}

Further energy savings can be obtained through minor process modifications. Process modifications have been implemented in the 

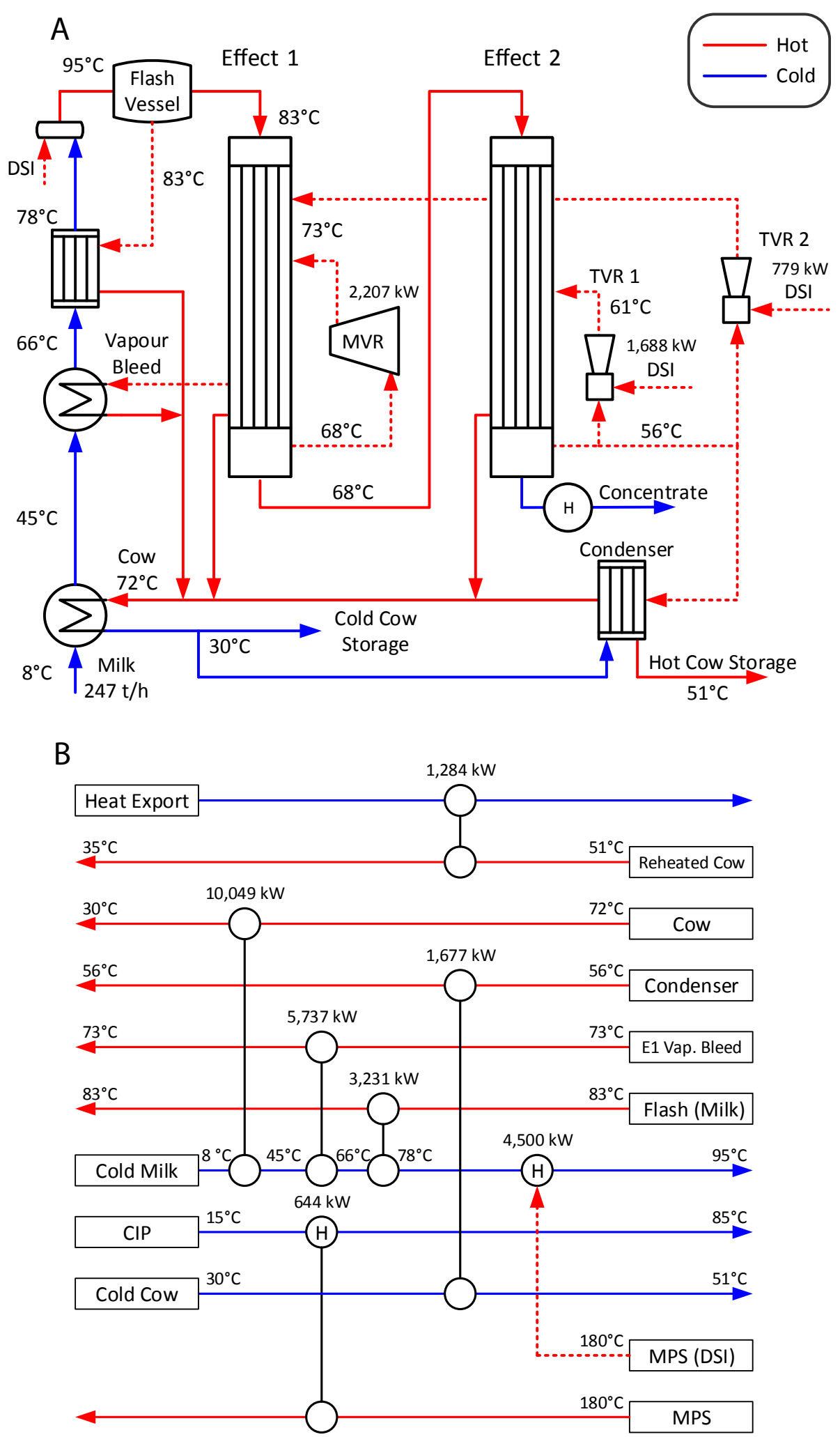

Fig. 3. Base-case industrial milk evaporator integration illustrated using a process flow diagram (A) and grid diagram (B).

detailed process model to ensure the numerous downstream impacts of changing a process variable, e.g. temperature, for the evaporation system are accounted for. New stream data may then be extracted from the model for reapplication of Pinch Analysis. When considering process modifications, the Plus/Minus Principle recommends to keep hot streams hot and to keep cold streams cold [26]. This principle is most effective for increasing energy recovery when applied to the stream that drives the Pinch [6], which in this case is the HT Milk Flash stream. There are multiple downstream effects from changing the HT Milk Flash temperature. This flash 
Table 1

Base case site stream data.

\begin{tabular}{lcccl}
\hline Process stream & $T S\left[{ }^{\circ} \mathrm{C}\right]$ & $T T\left[{ }^{\circ} \mathrm{C}\right]$ & $C P\left[\mathrm{~kW} /{ }^{\circ} \mathrm{C}\right]$ & $\Delta H[\mathrm{~kW}]$ \\
\hline Heat treatment and evaporator zone & & & \\
Cold milk & 8 & 95 & 272 & 23,557 \\
HT flash vapour & 83 & 83 & & 3231 \\
E1 vapour bleed & 73 & 73 & & 5733 \\
E2 Condenser & 56 & 56 & & 1677 \\
COW & 73 & 13 & 237 & 14,103 \\
CIP Water & 15 & 85 & 9 & 644 \\
Spray dryer zone & & & & \\
Concentrate & 56 & 70 & 49 & 692 \\
Dryer inlet air & 15 & 210 & 132 & 25,757 \\
FB inlet air & 15 & 95 & 66 & 5301 \\
HVAC & 15 & 25 & 53 & 5714 \\
Dryer roof zone & & & & \\
Exhaust air & 75 & 55 & 279 & 2250 \\
Boiler & & & & \\
Condensate & 85 & 40 & 50 & \\
\hline
\end{tabular}

Table 2

Base case site utility stream data.

\begin{tabular}{llcc}
\hline Utility stream & Type & TS $\left[{ }^{\circ} \mathrm{C}\right]$ & $T T\left[{ }^{\circ} \mathrm{C}\right]$ \\
\hline HPS & Hot & 250 & 250 \\
MPS & Hot & 180 & 180 \\
HTHW & Hot & 80 & 65 \\
LTHW & Hot & 55 & 35 \\
Cooling Water & Cold & 25 & 30 \\
\hline
\end{tabular}
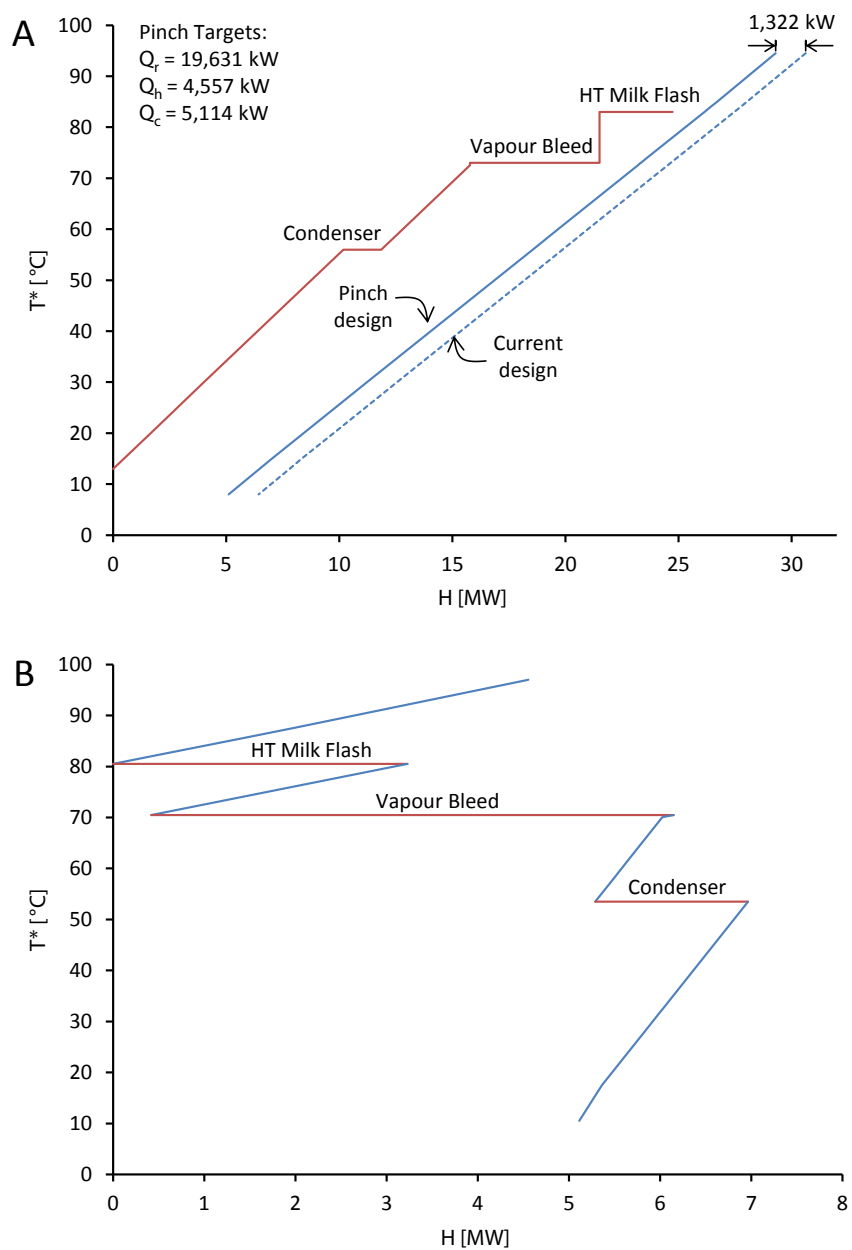

Fig. 4. CCs (A) and GCC (B) for the current evaporator design. temperature primarily affects: (1) the amount of flashing that occurs as the liquid milk feed enters the first evaporator effect; (2) the amount of required heat transfer in the first effect; (3) the required duty of the vapour bleed from the first effect; and, (4) the condenser duty. The development of a comprehensive process model was therefore an essential part of the Pinch Analysis and heat recovery design optimisation investigation.

Following the Plus/Minus Principle, the HT Milk Flash temperature has been increased by $0.7{ }^{\circ} \mathrm{C}$ in the process model and new targets calculated (Fig. 5). The new HT Milk Flash temperature was chosen so that two Pinches would occur on the GCC, which is an indication of maximum heat recovery [6]. As a result the heat recovery target increases by $199 \mathrm{~kW}$. Further increases in the HT Milk Flash temperature yield no additional benefit due to the second Pinch Temperature at $70.5{ }^{\circ} \mathrm{C}$ driven by the Vapour Bleed stream. The Vapour Bleed temperature, which is determined by the shellside operating pressure of Effect 1 , is constrained by the allowable operating temperature window for milk evaporators, which means it cannot be increased. As a result, the heat recovery target of $19,826 \mathrm{~kW}$ represents the best case design for the given evaporation system design.

\subsection{Appropriate placement of vapour recompression in new evaporation system designs}

A new evaporation system design can be developed by considering the appropriate use of vapour recompression. The integration of vapour recompression (either MVR or TVR) into an evaporation system should be ideally applied according to the appropriate placement principle for heat pumps. To develop the new design, the effects of the vapour recompression units in the current evaporation system on the stream data are removed and the evaporation/condensation occurring in the evaporator effects are added as stream data for the Pinch Analysis.

The GCC in Fig. 6A suggests Effect 1 should be integrated using MVR, as it is in the base case design. MVR is preferred since there is minimal opportunity to cascade heat through the evaporation system to heat other sinks [9]. The HSR (Heat Savings Ratio), which is defined in Eq. (2), for Effect 1 with MVR is 52. The GCC in Fig. 6B results from assuming Effect 1 is integrated with MVR and heat transfer within the MVR effect is removed from subsequent GCCs. The tube-side temperature of Effect 2 now drives the Pinch Temperature at $53.5^{\circ} \mathrm{C}$. There are three options to further improve energy efficiency: (1) integrate Effect 2 using TVR, (2) integrate

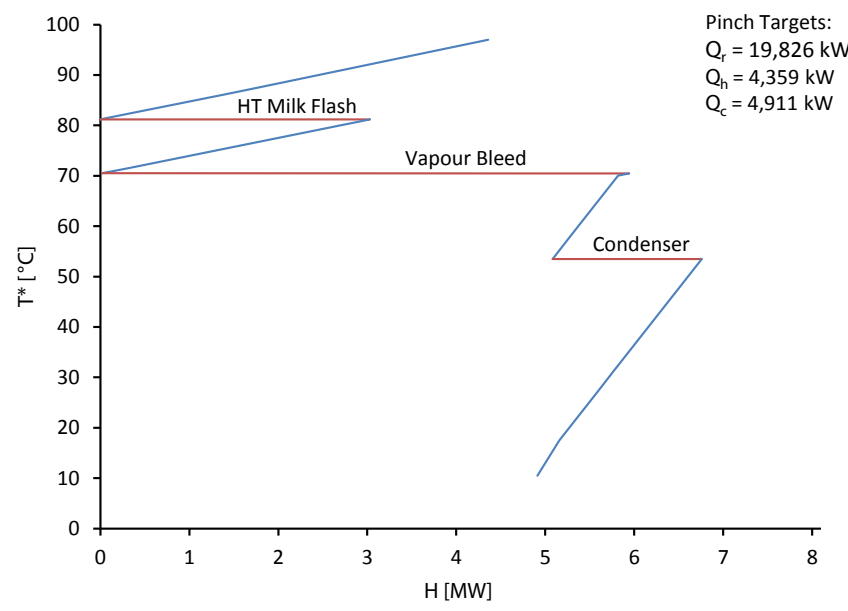

Fig. 5. GCC with new HT Milk Flash temperatures of $83.7^{\circ} \mathrm{C}$, given the current twoeffect evaporator set-up integrated with one MVR and two TVR units. 

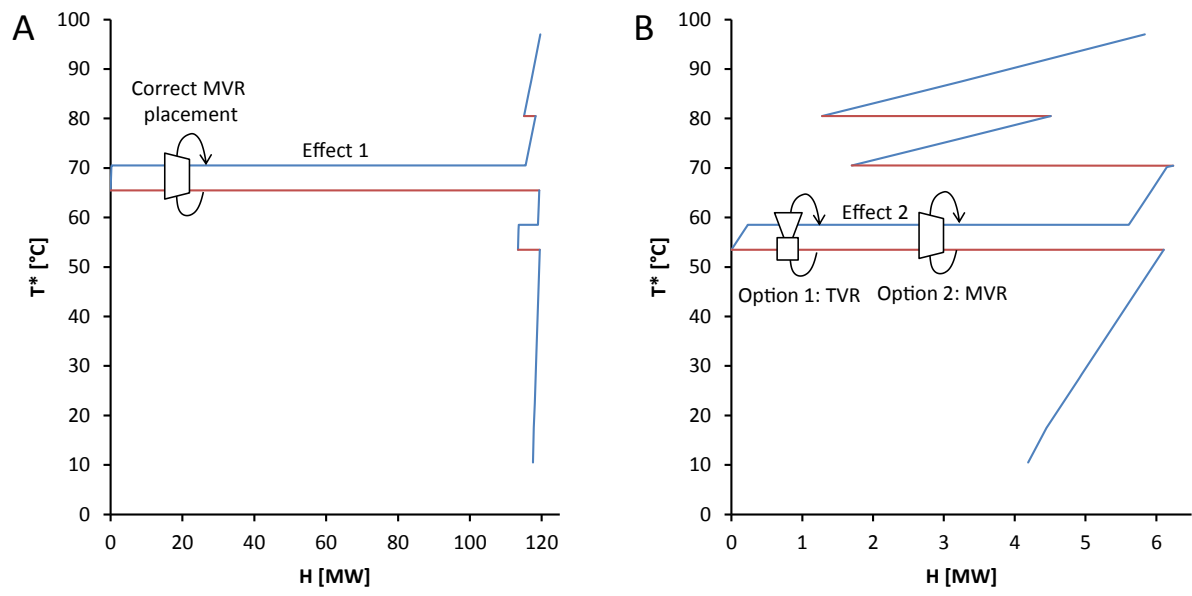

Fig. 6. GCC for evaporation system problem without vapour recompression (A) and with MVR for Effect 1 (B).

Effect 2 using MVR, and (3) add another effect that operates at $61^{\circ} \mathrm{C}$ with heat cascading from Effect 2 . This paper focuses on the first two options, while the third option, which requires an additional effect, is beyond the current scope. Using either MVR or TVR to integrate with Effect 2 also opens the possibility of additional vapour recompression for use in the milk heat treatment process. These options are explored using the GCC as an important tool for identifying the integration of vapour recompression in Figs. 7 and 8, with a summary of the corresponding energy targets in Table 3.

Fig. 7 presents the graphical development of a new MVR/TVR evaporation system design given Effect 1 uses MVR and Effect 2 uses TVR. The HSR for Effect 2 with TVR is -0.2 (Fig. 7A), which means the total steam use increased after including TVR for Effect 2. However, the use of TVR for Effect 2 helps identify that MVR should upgrade $3770 \mathrm{~kW}$ of heat from the shell-side of Effect 1 to directly heat milk above the HT Milk Flash temperature. Implementation of the changes shown in Fig. 7A results in an overall reduction in steam utility of $3835 \mathrm{~kW}$, which means the net HSR is 10.1 for the secondary MVR unit. The final GCC for the new MVR/TVR evaporation system is presented in Fig. 7B.

A second new evaporation system design may be developed given Effects 1 and 2 both use MVR (Fig. 8). The HSR for the MVR integrated with Effect 2 is 12.2 , which is substantially better than using TVR for this effect. Fig. 8A identifies MVR may be used to

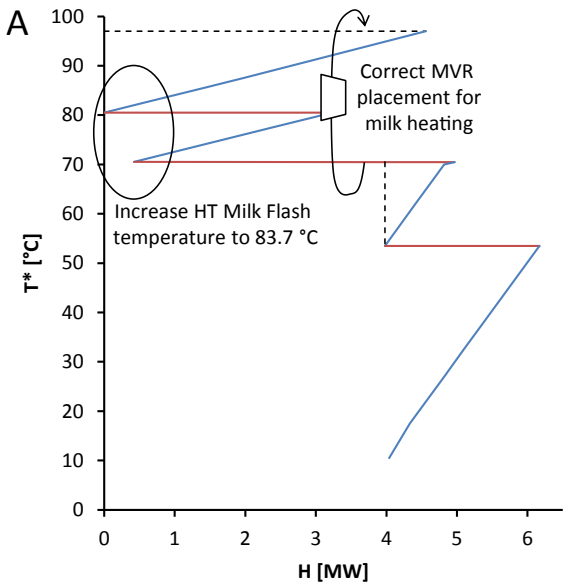

upgrade excess vapour from the shell-side of Effect 1 using 245 $\mathrm{kW}_{\text {ele }}$ to supply $2638 \mathrm{~kW}$ of heat to the cold milk sink. After implementing this additional MVR as well as the process temperature modification in Fig. 8A, a GCC for the new MVR/MVR evaporation system design may be determined as shown in Fig. 8B. The Pinch Region spans from $10.5{ }^{\circ} \mathrm{C}$ to $81.2{ }^{\circ} \mathrm{C}$ with no potential for heat export (unlike the current design) to neighbouring zones.

The new MVR/MVR design, from an energy use point of view, has marginally lower electricity and thermal energy use compared to the new MVR/TVR design. More important is the relaxed constraint around the Condenser load in the GCC of Fig. 8B compared the GCC of Fig. 7B. Since the Condenser is a significantly lower at a slightly higher temperature, it opens up more possibilities around the preheating of the milk. One unique milk processing constraint is only one heat exchange match should be used to heat milk through the high thermophile growth temperature range of $45-60{ }^{\circ} \mathrm{C}$, as to minimize the duplication of process lines. The new MVR/TVR design has a Pinch at $53.5{ }^{\circ} \mathrm{C}$, which means this constraint cannot be met. As a consequence, only the new MVR/ MVR design has been progressed to the HEN design stage.

\subsection{New ultra-low energy evaporation system design}

A new HEN for an ultra-low energy system has been developed given the placement of three MVR units as shown in Fig. 9. The

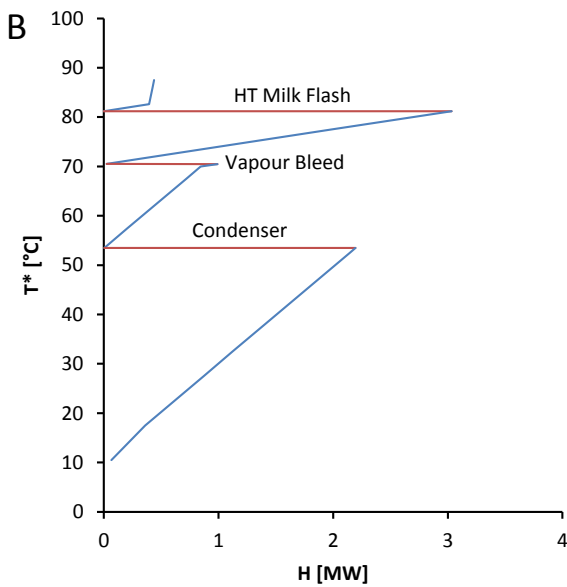

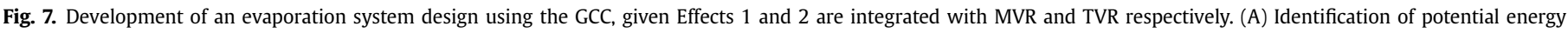
savings. (B) Final GCC for new MVR/TVR evaporation system design. 

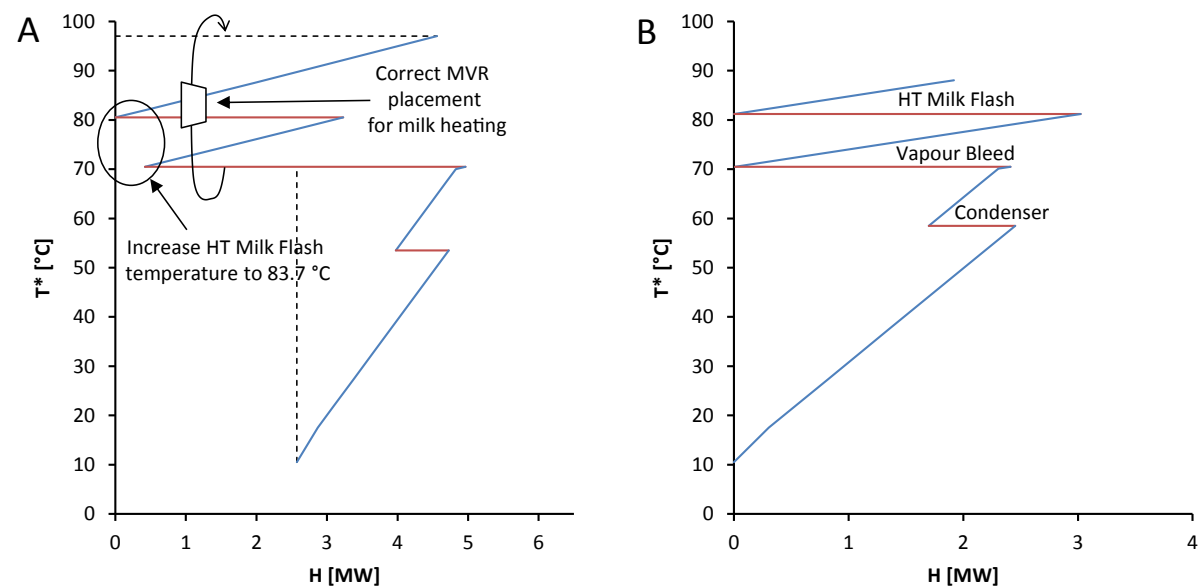

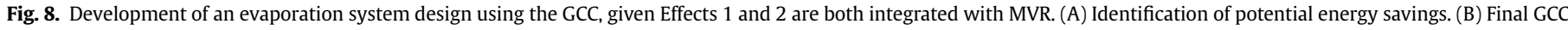
for new MVR/MVR evaporation system design.

Table 3

Summary of evaporation system energy targets for Figs. 4-9.

\begin{tabular}{|c|c|c|c|c|c|c|}
\hline Scheme (Figure) & $P T\left[{ }^{\circ} \mathrm{C}\right]$ & $Q_{e l e, M V R}[\mathrm{~kW}]$ & $Q_{h, T V R}[\mathrm{~kW}]$ & $Q_{h, o t h e r}[\mathrm{~kW}]$ & $\Sigma Q_{h}[\mathrm{~kW}]$ & $\Sigma Q_{c}[\mathrm{~kW}]$ \\
\hline Current (3) & - & 2207 & 2373 & 5878 & 8251 & 6435 \\
\hline 4 & 80.5 & 2207 & 2373 & 4558 & 6931 & 5114 \\
\hline 5 & $70.5-81.2$ & 2207 & 2373 & 4359 & 6732 & 4911 \\
\hline $6 \mathrm{~A}$ & 65.5 & - & - & 19,621 & 19,621 & 117,546 \\
\hline $6 \mathrm{~B}$ & 53.5 & 2207 & - & 5838 & 5838 & 4189 \\
\hline $7 \mathrm{~A}$ & 80.5 & 2207 & 1624 & 4557 & 6181 & 4038 \\
\hline $7 \mathrm{~B}$ & $53.5-81.2$ & 2582 & 1624 & 438 & 2003 & 65 \\
\hline $8 \mathrm{~A}$ & 80.5 & 2312 & - & 4557 & 4557 & 2566 \\
\hline $8 B$ & $10.5-81.2$ & 2557 & - & 1919 & 1919 & - \\
\hline New (9) & 10.5 & 2571 & - & 1854 & 1854 & - \\
\hline
\end{tabular}

estimated electrical and thermal energy uses for the completed new design are compared to the current design and various Pinch targets in Table 3. Compared to the current design, the new MVR/ MVR evaporation system design reduces steam utility use by $78 \%$ $(6397 \mathrm{~kW})$ at the expense of $16 \%$ (364 $\mathrm{kW}_{\text {ele }}$ ) increase in electricity use.

The HEN in Fig. 9 has four notable differences compared to the base case design in Fig. 3. First, there is a higher milk outlet temperature from the Milk/Cow match. The new design mixes lower temperature heat from the Condenser with the other condensate streams while also reducing the approach temperature of the Milk/Cow match. This changes results in an additional $4344 \mathrm{~kW}$ of heat transfer. The higher outlet temperature of $61^{\circ} \mathrm{C}$ also means the milk pass through the high thermophile growth temperature range in this heat exchanger. As a result, duplicate heat exchangers are required to ensure continuous processing, which is an important processing constraint. Second, there is a multi-stage MVR unit that upgrades heat from the shell-side of the first effect to heat milk. This important change was identified using the GCC in Fig. 8. Third, there is no longer excess low-grade heat available from the Condenser for export to heat dryer air flows. Fourth, Effect 2 is integrated with MVR instead of TVR. Fifth, there is now heat recovery to CIP water, where previously there was none.

Capital cost is also an important factor in determining the most economic evaporation system design and the total cost of a project. This paper focused on exploring to what extent energy reductions are possible in the milk evaporation system given certain processing constraints, without too much concern for capital cost implications. Rigorous capital costings of these designs compared to the current design will be the focus of future work.

\subsection{Total Site Heat Integration for the milk powder factory}

The milk evaporation system is a critical component and energy user of the milk powder production process. Major changes to the energy use profile of the evaporation system affect the site-wide heat balance. A comparison of four TSHI targets for the current plant design, the pinched current plant design, TSHI with the pinched current plant, and TSHI with the new MVR/MVR evaporation system design are presented in Table 4. It is important to note that the electricity use column only includes MVR electricity from the evaporation system.

An important difference between the first two targets and the last two targets in Table 4 is the inclusion of the Exhaust Air and Condensate streams as heat sources. Recovering heat from these streams can be challenging [32], but it is likely to happen in the near future as pressure on energy use and emissions increases. In the current design, $1284 \mathrm{~kW}$ of low-grade heat exports, which is counted as generation of LTHW, from the evaporation system are used to heat air streams in the Spray Dryer Zone. However, if heat is recovered from the Exhaust Air and Condensate streams, the marginal value of the heat exports from the evaporation system becomes nil. It is important to note that in practice there would not be a surplus of LTHW needing cooling, as indicated in Table 4. Instead, the design will only recover the amount of heat that is needed from the Exhaust Air flow given the balance of LTHW sources and sinks on the Total Site. 

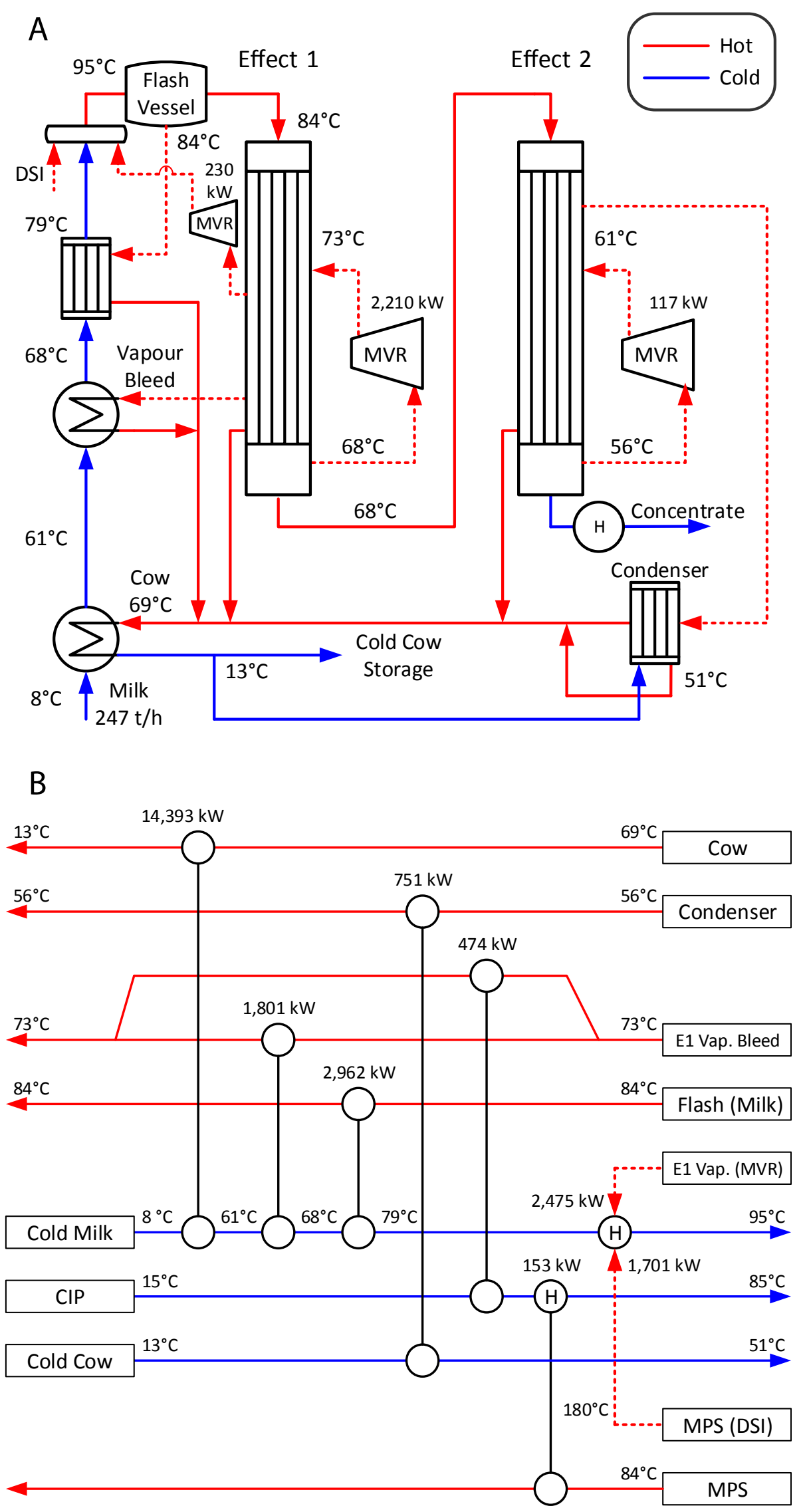

Fig. 9. New ultra-low energy milk evaporation system design illustrated using a process flow diagram (A) and grid diagram (B). 
Table 4

Summary of TSHI energy targets, energy cost savings, and emissions reduction.

\begin{tabular}{|c|c|c|c|c|c|c|c|c|}
\hline Scheme & & Electricity [kW] & HPS [kW] & MPS [kW] & HTHW [kW] & LTHW [kW] & Utility savings [\$/y] & $\begin{array}{l}\text { Emissions reduction } \\
{\left[\mathrm{t} \mathrm{CO}_{2}-\mathrm{e} / \mathrm{y}\right]}\end{array}$ \\
\hline \multirow[t]{3}{*}{ Current } & Consumption & 2207 & 5944 & 32,175 & 692 & 1815 & & \\
\hline & Generation & - & - & - & - & 1284 & & \\
\hline & Net & 2207 & 5944 & 32,175 & 692 & 531 & - & - \\
\hline \multirow[t]{3}{*}{ Pinched current design } & Consumption & 2207 & 5944 & 22,220 & 5650 & 5490 & & \\
\hline & Generation & - & - & - & - & 2922 & & \\
\hline & Net & 2207 & 5944 & 22,220 & 5650 & 2568 & $\$ 665,667$ & 2297 \\
\hline \multirow[t]{3}{*}{ Pinched current design and TSHI ${ }^{\mathrm{a}}$} & Consumption & 2207 & 5944 & 22,220 & 5650 & 5490 & & \\
\hline & Generation & - & - & - & $750^{\mathrm{a}}$ & $10,136^{\mathrm{a}}$ & & \\
\hline & Net & 2207 & 5944 & 22,220 & 4900 & -4646 & $\$ 1,411,844$ & 4872 \\
\hline \multirow[t]{3}{*}{ New evap. design ${ }^{\mathrm{a}}$ and TSHI ${ }^{\mathrm{a}}$} & Consumption & 2571 & 5944 & 17,057 & 5650 & 5490 & & \\
\hline & Generation & - & - & - & $750^{\mathrm{a}}$ & $7214^{\mathrm{a}}$ & & \\
\hline & Net & 2571 & 5944 & 17,057 & 4900 & -1725 & $\$ 2,354,446$ & 8288 \\
\hline
\end{tabular}

a Additional HTHW and LTHW generation from Exhaust Air and Condensate streams in TSHI schemes.

The utility savings from improving the current evaporation system design is $\$ 665,667 / \mathrm{y}$. About $45 \%$ of the utility savings arises from improved intra-Process Integration within the evaporation system, while the remaining 55\% of cost savings comes from increased LTHW generation. Heat recovery from Exhaust Air and Condensate has potential to contribute an additional \$746,177/y savings. Implementation of the new MVR/MVR evaporation system design delivers a further $\$ 942,601 / y$. In total, the achievable energy cost reduction is $23.1 \%$. For the final two targets, there is a lack of LTHW sinks within the milk powder process and so one option is to export heat to co-located plants (e.g. cheese, whey, casein, or butter plants) for large multi-plant sites using hot water loops [33].

The emissions reductions from implementing the various energy efficiency concepts have also been calculated. In New Zealand, the cost efficient replacement of thermal energy with electricity is a beneficial method for lowering emissions since the Emissions Factor from electricity $\left(0.129 \mathrm{t} \mathrm{CO}_{2}-\mathrm{e} / \mathrm{MWh}\right)$ is approximately half that of thermal energy from coal $\left(0.270 \mathrm{t} \mathrm{CO}_{2}\right.$-e/MWh $)$ [34]. As presented in Table 4, the emissions reduction potential for a $30 \mathrm{t} / \mathrm{h}$ milk powder factory by implementing the new evaporation system design provides an additional $3416 \mathrm{t} \mathrm{CO}_{2}-\mathrm{e} / \mathrm{y}$ beyond the $4872 \mathrm{t}$ $\mathrm{CO}_{2}$-e/y obtained by TSHI with a Pinched version of the current design. Overall this represents a $24.3 \%$ decrease in emissions from the entire site.

\section{Conclusions}

A new ultra-low energy, two-effect milk evaporation system design has been successfully developed. The Grand Composite Curve played a critical role in identifying process modifications and the appropriate placements of vapour recompression so to minimise energy use. In particular, the additional application of Mechanical Vapour Recompression in the system unlocks significant energy, cost, and emissions savings. The new design requires $78 \%$ less steam $(6397 \mathrm{~kW})$ at the expense of $16 \%\left(364 \mathrm{~kW}_{\text {ele }}\right)$ more electricity use. The estimated cost savings associated with the improved design is $\$ 942,601 / \mathrm{y}$ and the emissions reduction is 3416 t $\mathrm{CO}_{2}-\mathrm{e} / \mathrm{y}$. Further energy efficiency improvements are gained through improved Total Site Heat Integration by recovering heat from the dryer exhaust air and boiler return condensate streams.

\section{References}

[1] Klemeš JJ, Smith R, Kim JK. Handbook of water and energy management in food processing. Cambridge, UK: Woodhead Publishing; 2008.

[2] Klemeš JJ, editor. Handbook of process integration: minimisation of energy and water use, waste and emissions. Cambridge, UK: Woodhead Publishing: 2013.
[3] Ramírez CA, Patel M, Blok K. From fluid milk to milk powder: energy use and energy efficiency in the European dairy industry. Energy 2006;31:1984-2004. http://dx.doi.org/10.1016/j.energy.2005.10.014.

[4] Reay D. A selection of heat recovery applications illustrated by means of case studies. J Heat Recovery Syst 1982;2:401-18. http://dx.doi.org/10.1016/01987593(82)90028-5.

[5] Walmsley TG, Walmsley MRW, Atkins MJ, Fodor Z, Neale JR. Optimal stream discharge temperatures for a dryer operation using a thermo-economic assessment. Chem Eng Trans 2012;29:403-8. http://dx.doi.org/10.3303/ CET1229252.

[6] Walmsley TG, Walmsley MRW, Atkins MJ, Neale JR. Improving energy recovery in milk powder production through soft data optimisation. Appl Therm Eng 2013;61:80-7. http://dx.doi.org/10.1016/j.applthermaleng.2013.01.051.

[7] Atkins MJ, Walmsley MRW, Neale JR. Integrating heat recovery from milk powder spray dryer exhausts in the dairy industry. Appl Therm Eng 2011;31: 2101-6. http://dx.doi.org/10.1016/j.applthermaleng.2011.03.006.

[8] Walmsley TG, Walmsley MRW, Atkins MJ, Neale JR, Tarighaleslami AH. Thermo-economic optimisation of industrial milk spray dryer exhaust to inlet air heat recovery. Energy 2015;90(Part 1):95-104. http://dx.doi.org/10.1016/ j.energy.2015.03.102.

[9] Walmsley TG, Walmsley MRW, Neale JR, Atkins MJ. Pinch analysis of an industrial milk evaporator with vapour recompression technologies. Chem Eng Trans 2015;45:7-12. http://dx.doi.org/10.3303/CET1545002.

[10] Hanneman H, Robertson LJ. Heat recovery systems. In: Energy use dairy process. Brussels, Belgium: International Dairy Federation; 2005.

[11] Westergaard V. Milk powder technology. 5th ed. Copenhagen, Denmark: GEA Niro; 2010.

[12] Westphalen DL, Wolf Maciel MR. Pinch analysis of evaporation systems. Braz J Chem Eng 2000;17:525-38. http://dx.doi.org/10.1590/S0104-663220000 00400017.

[13] Modla G, Lang P. Heat pump systems with mechanical compression for batch distillation. Energy 2013;62:403-17. http://dx.doi.org/10.1016/j.energy.2013 .09.036.

[14] Janghorban Esfahani I, Kang YT, Yoo C. A high efficient combined multi-effect evaporation-absorption heat pump and vapor-compression refrigeration part 1: energy and economic modeling and analysis. Energy 2014;75:312-26 http://dx.doi.org/10.1016/j.energy.2014.07.081.

[15] Reddick C, Sorin M, Sapoundjiev H, Aidoun Z. Carbon capture simulation using ejectors for waste heat upgrading. Energy 2016;100:251-61. http:// dx.doi.org/10.1016/j.energy.2016.01.099.

[16] Townsend DW, Linnhoff B. Heat and power networks in process design. Part I: criteria for placement of heat engines and heat pumps in process networks. AIChE J 1983;29:742-8. http://dx.doi.org/10.1002/aic.690290508.

[17] Klemeš JJ, Dhole VR, Raissi K, Perry SJ, Puigjaner L. Targeting and design methodology for reduction of fuel, power and $\mathrm{CO} 2$ on total sites. Appl Therm Eng 1997;17:993-1003. http://dx.doi.org/10.1016/S1359-4311(96)00087-7.

[18] Klemeš JJ, Varbanov PS, Wan ASRW, Manan ZA. Process integration and intensification, saving energy, water and resources. Berlin, Boston: De Gruyter; 2014. http://www.degruyter.com/view/product/204103 [accessed 04.03. 16.

[19] Fritzson A, Berntsson T. Energy efficiency in the slaughter and meat processing industry-opportunities for improvements in future energy markets. J Food Eng 2006;77:792-802. http://dx.doi.org/10.1016/j.jfoodeng.2005 .08.005.

[20] Matsuda K, Hirochi Y, Tatsumi H, Shire T. Applying heat integration total site based pinch technology to a large industrial area in Japan to further improve performance of highly efficient process plants. Energy 2009;34:1687-92. http://dx.doi.org/10.1016/j.energy.2009.05.017.

[21] Matsuda K, Hirochi Y, Kurosaki D, Kado Y. Application of area-wide pinch technology to a large industrial area in Thailand. Chem Eng Trans 2014;39: 1027-32. http://dx.doi.org/10.3303/CET1439172.

[23] Bonhivers JC, Svensson E, Berntsson T, Stuart PR. Comparison between pinch analysis and bridge analysis to retrofit the heat exchanger network of a kraft 
pulp mill. Appl Therm Eng 2014;70:369-79. http://dx.doi.org/10.1016/ j.applthermaleng.2014.04.052

[24] Feng X, Smith R. Case studies of heat integration of evaporation systems. Chin J Chem Eng 2001;9:224-7.

[25] Al-Juwayhel F, El-Dessouky H, Ettouney H. Analysis of single-effect evaporator desalination systems combined with vapor compression heat pumps. Desalination 1997;114:253-75. http://dx.doi.org/10.1016/S0011-9164(98)00017-4.

[26] Linnhoff B. Introduction to pinch technology. Northwich, UK: Linnhoff March; 1998.

[27] MAF Quality Management. Physical properties of dairy products. 3rd ed. Hamilton, New Zealand: MAF Quality Management; 1996.

[28] Sargolzaei J, Pirzadi Jahromi MR, Saljoughi E. Triple-choking model for ejector. J Therm Sci Eng Appl 2010;2. http://dx.doi.org/10.1115/1.4002752. 021009021009-10.

[29] Oldfield DJ, Taylor MW, Singh H. Effect of preheating and other process parameters on whey protein reactions during skim milk powder manufacture. Int Dairy J 2005;15:501-11. http://dx.doi.org/10.1016/j.idairyj.2004.09.004.
[30] Baldwin AJ, Cooper HR, Palmer KC. Effect of preheat treatment and storage on the properties of whole milk powder. Changes in sensory properties. Neth Milk Dairy J 1991;45:97-116.

[31] Hinton AR. Thermophiles and fouling deposits in milk powder plants [PhD thesis]. Massey University; 2003. http://muir.massey.ac.nz/handle/10179/ 1861 [accessed 03.07.12].

[32] Walmsley TG, Walmsley MRW, Atkins MJ, Neale JR. Fouling and pressure drop analysis of milk powder deposition on the front of parallel fins. Adv Powder Technol 2013;24:780-5. http://dx.doi.org/10.1016/j.apt.2013.04.004.

[33] Walmsley TG, Walmsley MRW, Atkins MJ, Neale JR. Integration of industrial solar and gaseous waste heat into heat recovery loops using constant and variable temperature storage. Energy 2014;75:53-67. http://dx.doi.org/ 10.1016/j.energy.2014.01.103.

[34] Walmsley MRW, Walmsley TG, Atkins MJ, Kamp PJJ, Neale JR. Minimising carbon emissions and energy expended for electricity generation in New Zealand through to 2050. Appl Energy 2014;135:656-65. http://dx.doi.org/ 10.1016/j.apenergy.2014.04.048. 